that our health visitors should appreciate this point they are encouraged to keep a small "district" of their own. Ours is a pilot-scheme and will no doubt be modified in the light of experience, but I am grateful for the helpful criticisms of your correspondents. - I am, etc.,

$$
\text { Cardiff. }
$$

A. G. Watkins.

\section{"Grains" and " Grammes"}

SIR,-In the " Refresher Course for General Practitioners" on the dysenteries in the Journal of June 23 appears the advice to give " $1 \mathrm{~g}$. of phenobarbitone" as a sedative. In the case of less familiar drugs such a misprint might have serious consequences. Surely it would be safer and simpler to stick to tradition and quote "grains" before the numeral -e.g., "gr. 1 "-and " grammes" after it-e.g., " 1 g." ?I am, etc.,

Banstead, Surrey.

\section{J. B. JEFFRIES.}

${ }_{*}^{*}$ This regrettable mistake was due to a printer's error.ED., B.M.J.

\section{POINTS FROM LETTERS}

\section{Cartilage Retractor}

Mr. D. F. Thомаs (Scunthorpe) writes: The instrument described under the heading "A New Cartilage Retractor" (British Medical Journal, June 30, p. 1511) appears to me to be almost identical with the cartilage retractor described by $\mathbf{M r}$. $\mathbf{H}$. Jackson Burrows (British Medical Journal, 1937, 1, 273). The only apparent difference between the illustration in the recent description and $\mathrm{Mr}$. Burrows's retractor is a slight decrease in the size of the angle between the shaft and the blade.

\section{Ophthalmic Herpes Zoster and Aureomycin}

Dr. Bessie Goodson (Morden, Surrey) writes: I beg to add a clinical note concerning the treatment of ophthalmic herpes zoster, further to Dr. Fox's letter which appeared in the April 7 issue of the British Medical Journal (p. 760). On March 16 last I was consulted by a housewife, aged 57 , who complained of severe pain over the right eye. The minute vesicles of herpes zoster were already apparent. Within 24 hours the condition had deteriorated rapidly, and by the third day the eye was definitely involved. There was marked oedema of the lids and of the conjunctiva, and there were commencing signs of iridocyclitis. The patient was prostrate with pain and her general condition was very bad. The whole of the affected area of the face was covered by a confluent pustular eruption which suggested smallpox by its degree of severity. From the onset I had endeavoured to get the patient admitted either to a local hospital or a London eye hospital, without success. The Sutton Blood Transfusion Service immediately answered my appeal for "aureomycin," and I wish to acknowledge my indebtedness to them. The patient was given aureomycin by mouth in 500-mg. doses six-hourly. In all she was given $4,000 \mathrm{mg}$. over a period of 48 hours, at the end of which it was discontinued. Within 12 hours there was a dramatic change for the better. By the end of 48 hours from the time that aureomycin was first given all eye symptoms had subsided. The severe pain was completely alleviated, the condition of the skin had cleared, and only a few dry clean crusts remained. The whole attack from the appearance of the vesicles was cut short to a little over seven days. No other treatment was given and no local applications other than dry starch powder were used. It would seem, therefore, that it would not be fair altogether to condemn the use of aureomycin in cases of ophthalmic herpes zoster. In my own personal experience I have never known any of the advocated remedies, expensive or otherwise, prove comparable with aureomycin in the success attained.

\section{Corrections}

Dr. F. S. Lavery writes: In the article "Use of Cortisone in Diseases of the Eye" (June 9, p. 1285) (1) In the table of cases, under Sympathetic Ophthalmia, the last sentence should read: "The other case which came under treatment when the condition had been long established was not improved." (2) In General Discussion, Case 3, Sympathetic Ophthalmia, the first line should read: "May 10, 1950."

Dr. K. W. Cross writes: In the second sentence of the first paragraph of our paper "Asphyxia Neonatorum Treated by Electrical Stimulation of the Phrenic Nerve" (May 12, p. 1043) we stated that Hufeland used the phrenic-nerve stimulation in the patient. This is misleading, since his "patients" were dogs.

\section{Obituary}

Dr. Frank Robinson, who was for many years in practice at Astley Bridge, Bolton, died at Astley Bridge on June 6 , in his 70th year. The son of the late Dr. James Robinson, he had several brothers who also entered the medical profession, and he could trace eleven members of the family, past and present, who had become doctors. Frank Robinson was educated at Epsom College and Manchester University, where he graduated M.B., Ch.B. in 1904. Later he entered general practice in the Astley ,Bridge district of Bolton, where he established a large practice. He was an exemplary general practitioner, being methodical, capable, and attentive to his work. He had an excellent knowledge of what general practice entailed, and had decided views on the present state of the medical profession, and, although he never held any official post, he was a regular attender at the medical meetings. It had been noticed that his health was failing for some months past, but he continued at his work until the end, being taken ill while serving on a medical recruiting board. He died four days later in hospital. He was a member of insurance, recruiting, and pensions boards. During the first world war he served in the R.A.M.C. along with his brothers, one of whom was killed. He was a keen Rugby player in his early days and played for Manchester and Bolton Rugby Clubs. Our sympathy is extended to his widow and three sons; two of his sons are Fellows of the Royal College of Surgeons of England, and the third hopes to continue his father's practice.-J. F.S.

Dr. G. E. N. BIRD, who was for several years in practice in Burnley, died at his home in Burnley on June 8. The son of the late Dr. A. E. Bird, George Edward Noel Bird was educated at Warwick School and Christ's College, Cambridge, where he graduated M.A. in 1933. From Cambridge he went on to St. Bartholomew's Hospital and, after qualifying in 1938, entered his father's practice in Burnley. From 1940 to 1943 he was in charge of a first-aid post under the civil defence scheme. He served in the R.A.M.C., mainly in the Middle East, from 1943 to 1946, attaining the rank of major before returning to his home town. It was indeed tragic that so soon after his return he was to be struck down at the early age of 44 by a painful and distressing disease, from which he died a year later. "Dicky," as we all knew him, was a lovable character, kindly, thoughtful, and with a delicious brand of quiet humour. It was characteristic of him to inquire about his patients and see the humour of their lives up to a few days before his death. He met his end bravely and without bitterness. Our sympathy goes out to his widow, who nursed him so devotedly in his long illness, his small son, and his mother.-C.E. B. L.

Mr. P. G. L. EsseX-Lopresti, a consultant surgeon to the Birmingham Accident Hospital, died suddenly at his home at Olton, on June 13, at the early age of 36. Peter Gordon Lawrence Essex-Lopresti studied medicine at the London Hospital, qualifying in 1937. After holding the appointment of resident anaesthetist at the London he took the D.A. in 1938. Thereafter he returned to surgery and held a number of residential surgical posts. He became a Fellow of the Royal College of Surgeons of Edinburgh in 1942. During the war he served with an airborne division and attained the rank of major in the R.A.M.C. After demobilization he decided to specialize in accident surgery and joined the staff of the Birmingham Accident Hospital and Rehabilitation Centre.

Mr. William Gissane writes : Peter Essex-Lopresti set his standard in surgery and in life itself at a very high level, and his spirit and practical ability enabled him to meet that standard. His contributions to surgical literature were many and noteworthy for one so young: "The Hazards of 